\title{
THE \\ PROBLEM OF FORESTRY \\ IN \\ MINNESOTA. \\ REPORT TO THE \\ State Forestry Board \\ OF \\ Minnesota.
}

BY

BY C. A. SCHENCK, PH. D.,

FORESTER TO THE BIL,TMORE, ESTATE, BILTMORE, N. C.,

FOREST ASSESSOR TO THE GRAND DUCHY OF HESSE-DARMSTADT, AND

PRINCIPAL, BIL,TMORE, SCHOOL, OF FORESTRY. 

$\because \because \because$

$\because 0$ 
$\therefore \because \because \because \vdots \vdots \vdots \cdots$
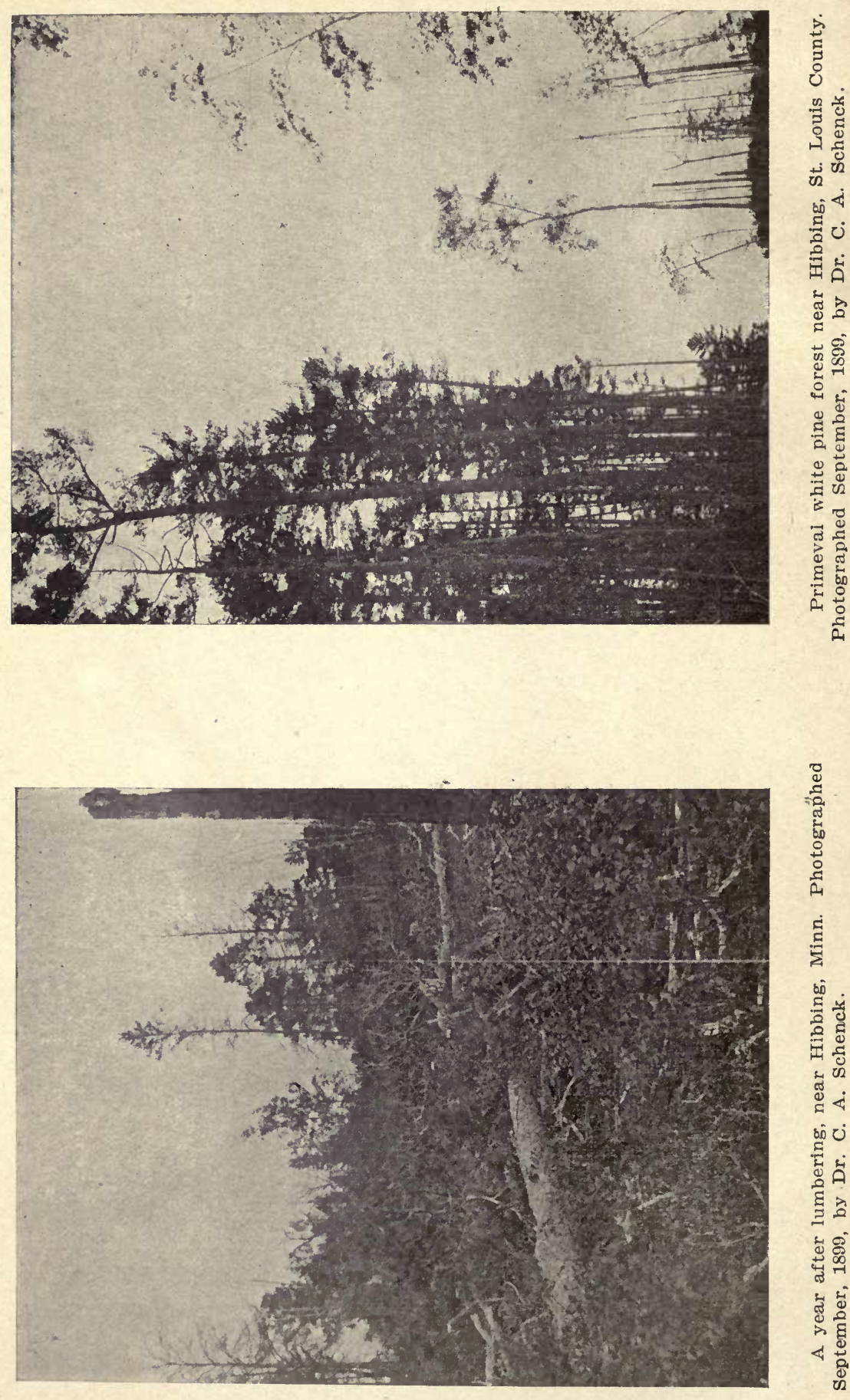

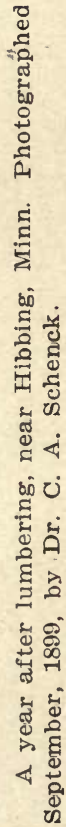




\section{THE}

\section{PROBLEM OF FORESTRY}

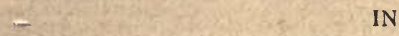

\section{MINNESOTA.}

REPORT TQ THE

\section{State Forestry Board OF}

\section{Minnesota.}

BY

BY C. A. SCHENCK, PH. D.,

FORESTER TO THE BILTMORE, ESTATE, BILTMORE, N. C.,

FOREST ASSESSOR TO THE GRAND DUCHY OF HESSE-DARMSTADT, AND PRINCIPAL, BILTMORE SCHOOL, OF FORESTRY.

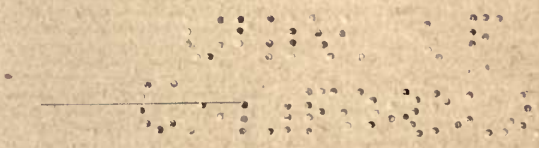

ST. PAUL, MINN.

PRINTED BY THE PIONEER PRESS COMPANY, 


\section{ORGANIZATION}

OF THE

\section{Minnesota State Forestry Board}

JUDSON N. CROSS, President, Minneapolis, Minn.

GREENLEAF CLARK, Vice-President, St. Paul, Minn.

C. C. ANDREWS, Secretary, St. Paul, Minn.

\section{MEMBERSHIP OF THE BOARD.}

C. C. ANDREWS (ex-officio as Chief Fire Warden)............ St. Paul, Minn. SAMUEL B. GREEN, (ex-officio as Horticulturist,

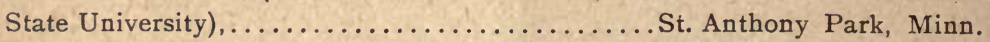

The following three members recommended by the Regents of the State University, and to hold for a term of four years:

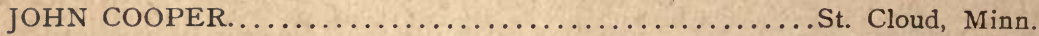
FREDERICK WEYERHAEUSER.................... Paul, Minn.

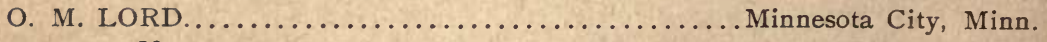

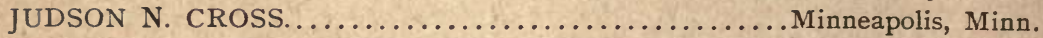

(Recommended by the State Forestry Association, and to hold for two years.)

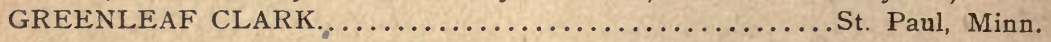

(Recommended by the State Agricultural Society, and to hold for two years.)

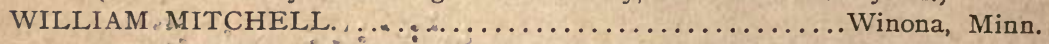

(Recommended by the Game and rish Commission, and to hold for two years.)

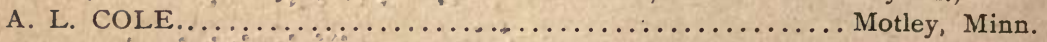
(In place of Charles A. Duncart, of Duluth, who was recommended by the State Horticultural Society, but declined.) 


\section{DR. SCHENCK'S REPORT.}

At the invitation of the State Forestry Board of Minnesota, Dr. C. A. Schenck, Ph. D., trained in the science and practice of German forestry and for several years superintendent of the estate of Mr. Geo. W. Vanderbilt at Biltmore, North Carolina, visited the forest regions of Minnesota last September and afterwards submitted to the board the following report:

\section{The Problem of Forestry in Minnesota.}

ECONOMIC USE OF THE SOIL.

The possibilities for economic use of soil are threefold. Soil may be devoted to the production of field crops (agriculture), or to the production of animal matter (pasture), or finally to the production of wood crops (forestry). In America, only agriculture and pasture are considered as soil industries. Land unfit for either of the two is thrown away. Forestry as a remunerative use of national soil is entirely disregarded. In the case of private individuals, ignorance relative to the economic value of forestry can be easily excused. Government itself, be it of democratic, republican or populistic strain, sets the example in dealing carelessly with the forestry problem.

It has been and is the policy of state and federal government to leave the development of all sections of the country to private enterprise. Under this freedom of action, the agricultural districts have shown an unparalleled rate and steadiness of development. In sections, however, where there is a comparative scarcity of soil fit for such farming as can compete in the general market, it has been and will be impossible for private enterprise to undertake the development of the whole region. Proof of this statement lies, for instance, in the Adirondacks, in the Alleghanies, in the pineries of the Carolinas, and in certain sections of Michigan, Wisconsin and Minnesota. At the present density of population, the present wages of manual labor and the present prices of field crops, soil of poor quality can be used only for pasture or for sylviculture. Pasture is not practicable, where the wintering of stock cannot be well effected, be it for climatic rèasons, be it for lack of winter forage. Pasture is not permissible where it results in rapid deterioration 
of the soil. Pasture is not advisable where tree growth will furnish a higher and safer revenue. Has it never occurred to the men framing this country's destiny, that on millions of acres embraced in this country, tree growing might possibly be the most remunerative industry? Is it not a function of government to see that every acre of national soil be devoted to the most remunerative production? Have our governments, or rather we, the people ruling this country, done our duty? Look at the millions of acres lying absolutely unproductive in almost every state of the Union. A few decades of years ago they bore a growth, a growth of trees. Now the barren appearance of the soil bears testimony of our economic thoughtlessness. Private enterprise, after having made a clean sweep of the primeval trees, did not find it practicable to use the soil for forestry or sylviculture, the only use to which it is adapted. The bare land was neglected and cast aside. The governmental land policy, when turning absolute forest land over to private enterprise, ought to have foreseen the consequences. It was wrongand it is wrong - as far as sections unfit for agriculture and for stockraising are concerned. It is deaf to the main demand of political economy: "Do not allow a square foot of national soil to lie idle." The small farm holdings occupying the better ground in such artificial deserts, denuded from tree growth, look gloomy; the soil is worn out; miserable roads and inadequate schools characterize the region. Such unpleasant conditions are not the fruit of poor soil. They are the fruit of a preposterous use of poor soil.

In European countries, poor soil is used for forestry. The inhabitants of forest districts occupy small villages along the bottoms of creeks and rivers; the little patch of farm land does not feed the family. It is work in the forest on which the backwoodsman chiefly makes his living. Abroad we find a strong, energetic population in the forests, in spite of the poorness of the soil. In this country we find in sections productive of forest, though not destitute of it, a population thriftless and discontented.

There is nothing new in these observations. Every educated American is aware of the facts. Our legislatures, however, have not had time to consider the forestry question, which is perhaps not as urgent, but in my opinion more important, than the problems of trusts and expansion.

MINNESOTA'S INTEREST IN FORESTRY.

For merely agricultural states, like Iowa and Ohio, where all land is fit for farming, forestry is, of course, only a national matter. 
For other states, and preëminently for Minnesota, it is a state problem of first importance. - By far the larger portion of Minnesota, the prairies and the former hardwood belt, contain splendid farm land. Clearing of hardwood land is still in progress, and we can only hope that on every acre of fine soil the plow will soon follow the axe. On such ground agriculture yields higher net returns than timber growth, and a small wood lot on the farm is all the settlêr should desire to maintain. The character of the northeastern section (under northeastern section is understood the corner north of the $47^{\text {th }}$ degree of latitude and east of the $95^{\text {th }}$ degree of longitude) of Minnesota is entirely different. Farm land-I mean farm land about as good as prairie land-is scarce. Corn is an uncertain crop. Nature itself has designated the soil as poor by raising a crop of pines on the ground - pines making smaller demands on the fertility of the ground than hard woods.

Stock pasture is possible in many sections; still the length and severity of the winter, combined with the impossibility of raising sufficient winter forage, prevent stock farming on a large scale. Undoubtedly the most economic use to which the bulk of the northeastern section of Minnesota can be devoted, is forestry. There is, of course, many a spot on which potatoes and vegetables can be raised and which allows of farming on a small scale. However, unless the settler finds additional and remunerative work in the forest and a local market for his field products in the logging camp, the prospects for farming are gloomy. In the northeastern corner of Minnesota, as far as the best use of the soil is concerned, forestry must form the rule and farming the exception.

In the south and west of Minnesota, agriculture is the best possible soil industry, almost to the exclusion of the forest. Between the typical forest region of the northeast and the typical farm region of the west and south, lies a strip where forestry and agriculture should occupy equal shares of soil, always with a view of obtaining the best economic result for the commonwealth.

There is no doubt that gradually agriculture and forestry would adjust themselves to their respective precincts if the latter were given an equal chance in the hands of private individuals. Under the conditions prevailing in North America, however, forestry is an investment not sought for by private enterprise.

THE CAPITALIST AND FORESTRY.

The reasons for capital failing to engage in forestry lie in the danger from fire to which forests are exposed; in overtaxation 
from the side of the county; further, in the unwieldiness of forestry as a business - a quality which does not allow of speculation, of unexpected gains and of ready sale - in the large size of the areas required for proper forest management, in the impossibility of entailing forest property, in the state laws preventing corporations from controlling over 5,000 acres of land, in the length of time required to develop a tree out of a seedling, in the uncertainty of future yields, due to an absolute lack of statistics, and many other particularities of forestry which it would lead me too far to enumerate.

Private individuals, I am confident, will not embark in forestry unless considerable inducements are offered. These inducements must do away with the main obstacles to conservative forestry - preeminently with the danger from fire. The forestry problem of Minnesota is almost identical with the forest fire problem. If there were no fires, a second growth would invariably follow the removal of the virgin growth, even against the wish of the land owner. As long as fires prevail, desolate barrenness takes possession of the land after lumbering. Hundreds of thousands of acres lying idle in every state of the wooded east and west - in Minnesota over 2,000,000 acres - bear witness to the truth of the statement.

The American people commit a great economic mistake when considering land as unproductive which is unfit for agriculture. On an average, the annual production of timber on an acre of forest land is about 160 feet board measure, worth standing on the ground about 40 cents.

\section{THE WAGE EARNER AND FORESTRY.}

Even if protection from fire should cost all of these 40 cents, the people will make a gain : I6o feet of lumber, when manufactured into ceiling, siding, sheathing, flooring, doors, boxes, furniture, carriages, paper pulp, etc., are worth at least $\$ 4.00$, the difference of $\$ 3.60$ consisting almost entirely of wages earned by manual labor. We lose one of the best chances for remunerative employment of labor if we allow forest land to go to waste. In semi-agricultural districts, where work is scarce during winter, this fact weighs doubly, and similar considerations hold good for certain mining districts where operations are discontinued during the cold weather.

If $2,000,000$ acres of forest land in Minnesota are lying unproductive, the state loses annually a chance for $\$ 8,000,000$ worth of 
manual labor. Another $10,000,000$ acres will have the same fate unless the people of Minnesota recognize the necessity of taking immediate action. The hygienic and æsthetic drawbacks of deforestation have been shown the people sufficiently; the influence of vanishing forests on water supply, navigation and local climate is generally known. But the fact that the practice of forestry is just as necessary on poor soil as the practice of agriculture on good soil, has not sufficiently impressed the public mind yet.

\section{MINNESOTA'S LAW RELATIVE TO STATE FORESTS.}

All land which the state of Minnesota now owns, land of agricultural quality as well as non-agricultural land, is not meant to be kept for state purposes; state land is to be disposed of, as soon as an opportunity for sale offers itself. While such a course, without a doubt, in the case of soil fit for farming, is highly commendable - in the case of nonagricultural soil fit for tree growth only, it is with no less doubt objectionable; nonagricultural land in Minnesota, in the hands of private individuals, is doomed to become and to lie barren, whilst it could produce, in the conservative hands of the people, a sustained yield and a rising annual revenue.

The explanation of the fact, that forestry practiced by the people is sure to be remunerative, whilst private individuals do not believe in it, lies in the following points:

r. Forestry is a clumsy investment, not allowing of quickminded speculation, of sudden gains, of steady, even annual returns. The values created are, to a large extent, prospective values, which do not allow of ready sale.

2. The returns are not apt to be higher than 6 per cent on the capital. They cannot be much increased, owing to natural limitations, by the owner's ingenuity.

3. The investments are suffering from preposterous taxation, left at the mercy of short-sighted county officials.

4. The forest is constantly endangered by fires; on small and scattering holdings this danger is particularly great. The more compact and the larger the area under forest, the easier is forest protection.

5. The beneficial effect of the forest upon water-regulation, climate, public health, public sport and recreation is a return from the forest, that does not flow into the pockets of an individual owner, whilst for the people these blessings offered by the forest are worth many a dollar. 
Recognizing the truth of these points, the legislature of the state of Minnesota has created a state board of forestry and has authorized it to accept gifts of land for forestry purposes. Although tentative only in its immediate bearing, the step was decisive in as far as it acknowledges the advisability of a state forestry system. If the gifts expected to be made by private generosity consist of small and scattering tracts only, the state board will find it difficult to make the undertaking yield immediate returns, especially so if the tracts are entirely denuded of timber. For in that case a considerable outlay is required in order to artificially replant the land, which, if mother-trees were left, would have been done by nature alone. The expense of reforestation, using 5, ooo seedlings of white pine per acre, will be about $\$$ II.25. The annual appropriation put at the disposition of the Minnesota State Forestry Board $(\$ I, 000)$ will allow it to annually reforest about 90 acres of denuded land. The development of such plantations is shown by the enclosed photographs taken on the Biltmore estate, where about 300 acres of abandoned farmland were replanted with white pine. It is worth mentioning that no pine species, in my opinion, is more easily transplanted and raised than white pine. The success is more certain still, if only a few years have elapsed since the denudation of the land. Before planting, the debris left on the ground should be burned, so as to reduce the danger from fires.

If land cut over and not bare of timber should be deeded to the state for reserve purposes, a different course must be followed. Artificial planting can be dispensed with, unless the soil is covered exclusively with worthless brush. Protection from fire is the main task. The best specimens of valuable species, if dangerously suppressed by worthless poplars or birches, might be given slight assistance. An absolute freeing, however, is not advisable. Every case has its own requirements. There does not exist any general prescription fitting every case, in forestry no more than in medicine. Every case must be dealt with according to its peculiar necessities, -always with the best monetary result at stake. In forestry, it cannot be repeated often enough, there is no more room for sentiment than there is in agriculture.

Should private generosity put the state forestry board in charge of any virgin forests containing marketable timber, the board should at once proceed to sell the mature and hyper-mature trees to the highest bidder. Whilst these "idlers" are being removed, a young growth of seedlings will establish itself free of charge, provided that fires are kept out. If the cutting proceed gradually 



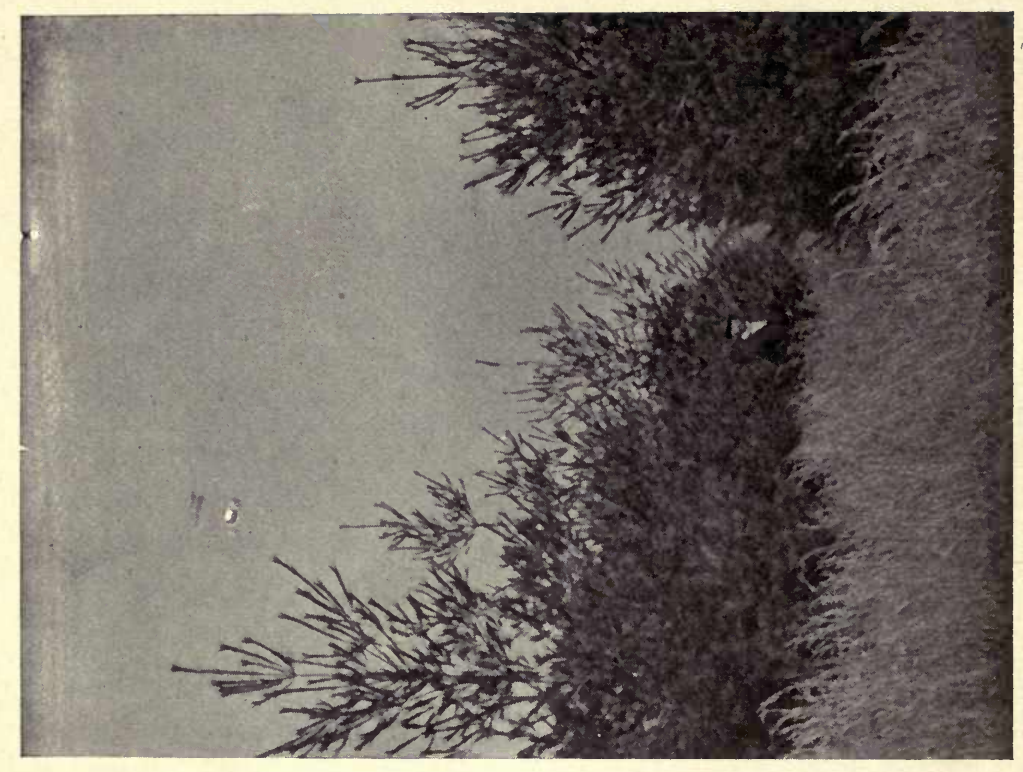

壳官

동

实

की

$\infty$

고

噌

叫

영

ㄷํำ

ชิ

路

โี 듀 రึ

융형

品 on

돓

$\because \Delta$

능

สี क्ष

$\overrightarrow{4}$ क

म्न

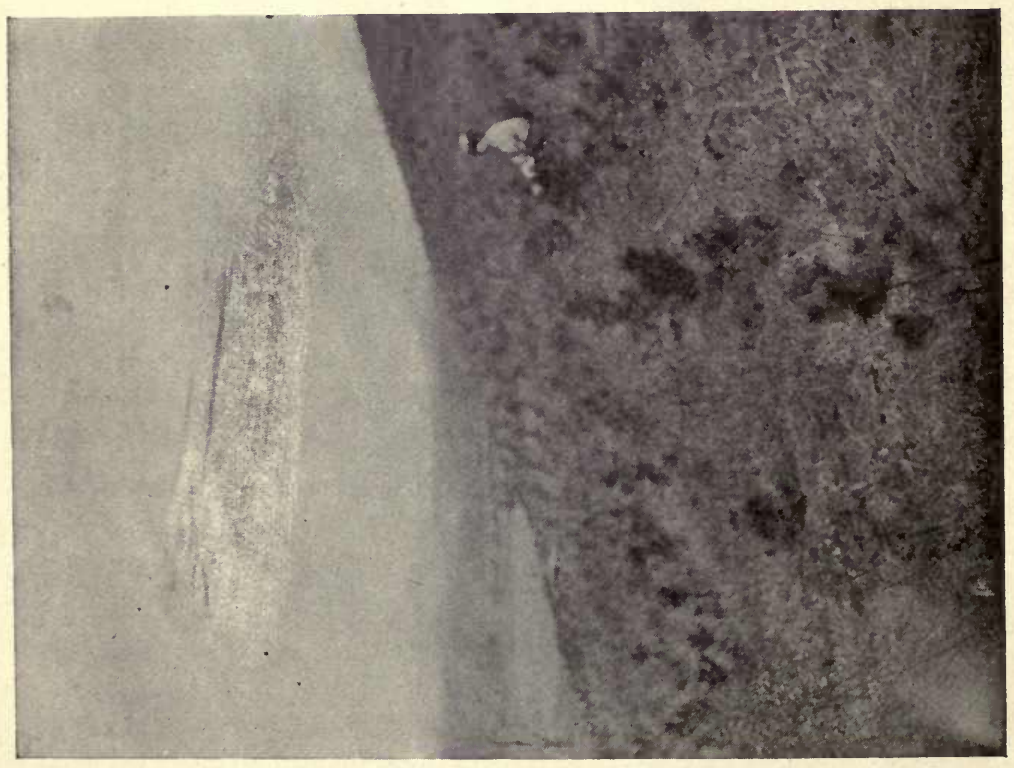

द्व

के

出

म्ञ

㶽

5

氙

م

'ठ

हี

훙

สํ 댕

๘ 0

뎡르연

(1)

고

घ․

茟

is

욤

द

สำ

语品 
towards the prevailing wind direction, damage from wind-falls can be greatly restricted. Obviously the logging expenses under forestry are slightly higher than in destructive lumbering. The prospective value of the second growth started by forestry will, however, more than offset the excess of logging expenses, or, which is the same, the smaller stumpage prices obtained.

If an industry works at a loss, it should, of course, not be maintained artificially. Forestry, however, never works at a loss; I do not hesitate to say, it is the only industry which never knows financial failure. Proof of my testimony lies in 200 years of forest history abroad. A seedling once well planted is sure to develop into a tree; and as sure as the value of a tree is higher than the value of a seedling, forestry pays interest on the capital invested and repays the capital. True, the interest is small, being counterbalanced by expenses for protection, administration and taxes, all of which accumulate at compound interest up to the year at which the trees reach maturity. If, however, protection and administration are done on a large scale, the annual charges per acre of forest are small; and if the assessment of forest land is not at the mercy of shortsighted county politicians, 2 to 4 per cent of annual interest on the investment will be left, even if stumpage prices do not rise in the future. Thus the forest will yield small but safe interest. High returns from forestry are impossible, because trees, generally. speaking, do not grow at a Io-per-cent rate. They grow slowly, but they grow as regularly as the sun shines, the rain falls, the wind blows; for sunshine, rainfall and air are the components of wood.

The federal and state laws dealing with land problems are framed only to suit the character of agriculture. The acquisition of large tracts, so essential for forestry, is rendered almost impossible. The entailing of real estate so necessary where decades of years lie between time of planting and time of harvesting, as is the case in forestry, is unconstitutional. Corporations, which by an issue of shares, marketable on exchange, might facilitate the salableness of forest property, are not allowed to own over 5,000 acres of land. The land laws induce the settler to rather become a land speculator - but there is no room for land speculation in forestry.

The practice of selling absolute forest land in small lots must result in forest destruction and the people allowing it to continue are guilty of a criminal neglect. Settlers farming such land, when the soil is exhausted and when no work is available in the deserted 
neighborhood, become a prey of disappointment and demoralization. Still, under existing laws, the government is not permitted to withdraw such land from private sale and to embark in forestry as a business on its own account, industrial functions of government not being considered democratic.

THE VIIRGIN FOREST.

The primeval forest containing many thousand feet board measure per acre is not at all the forester's ideal. Such a forest is unproductive; the annual formation of wood is exactly offset by the annual deterioration and death of hyper-mature trees. Ths primeval forest is an idling capital, is economically objectionable.

I have said elsewhere that sunshine, air and rain are the chief factors of wood. The forester simply "bottles" those three ingredients into tree-boles. As the same causes must have the same effect, under otherwise equal conditions, a given amount of leafy surface and root system, whether it belongs to young saplings, middle-aged poles or old trees, must necessarily form an equal amount of wood. Hence the young forest, containing only 1,000 feet board measure grows at a high rate of interest; the old-although sound-forest grows at a rate of about $\mathrm{I} / 2$ per cent. As soon as a forest ceases to grow at a sufficient rate, it must be cut and replaced by a new forest. Nature is ready to answer the task of regeneration. Since thousands of years it has replaced one generation of the forest by another. There is no reason why it should stop work at the threshold of the 2oth century, if men do not change the natural conditions.

THE IDEAL FOREST.

The large majority of the trees in the ideal forest consist of small specimens; for only those grow at a high rate of interest. The oldest ones, towering over an abundant progeny of second growth, are removed when they reach the minimum rate of growth permissible, much for the benefit of the progeny, which after their parents' death enjoy the unrestricted blessings of sunshine, rain and air.

In the ideal forest, some trees are Io, others $20,30,40,50$, and so on, years old. Suppose the oldest ones, roo years old, are now removed. They will be replaced quickly by young seedlings filling the gap. The forester returning to that neighborhood after Io years, finds a composition of the forest identical with the one previously met with. Trees prevlously go years old are now Ioo 
years old, and the forester again proceeds to remove the centenaries, the oldest age class.

The average stand of trees per acre in the ideal forest is little, say 2,000 feet to 4,000 feet board measure per acre. It must be the forester's aim to reduce the stumpage found in the primeval forest as quickly as possible to the ideal figure. Only that amount of capital is left in the forest which yields the highest interest in the safest manner.

There are, of course, many difficulties and drawbacks associated with a course as outlined. The lumbering expenses are increased; the storm is apt to play havoc in the new forest, at least to begin with; insect plagues are to be feared; the owner's capital is kept scattered over a large area, etc. Still, these inconveniences and dangers weigh little compared with the influence which reckless taxation has on the amount of revenue obtainable from the investment and which forest fires exercise on the safety of the capital engaged.

NECESSARY PREMISES FOR PRIVATE FORESTRY.

Give the wood-owning lumbermen protection against hypertaxation and protection against conflagration, and he will practice forestry on nonagricultural land, because it will pay him best to do so. In addition, cancel the law preventing companies from holding over 5,000 acres of land; gather statistical data relative to the rate of tree growth, through the St. Anthony Park station so well equipped for the task, so as to do away with the uncertainty enveloping the financial possibilities of tree growth. If you want to develop a desirable industry you will have to offer inducements allowing that industry to become remunerative.

As regards taxation, it is unwise to leave forest property at the mercy of mere local authority. All nonagricultural land, with the help of the geological survey, should be singled out and its taxation regulated by state authority. Young trees yielding a revenue only after decades of years cannot stand much taxation. The state deriving a direct benefit from the maintenance of forests, should be held to bear part of the tax burden.

As regards protection from fire, the state of Minnesota, through its fire-warden system, has made a timid step in the proper direction. That amount of safety however, which the owner of the forest requires for it, cannot be secured at the small appropriation set aside for forest protection. Unless the comparatively small 
revenue derivable from forestry is absolutely safe, no one will care for forestry as an investment.

"Economy, is the highest virtue of a legislature." But is it economy to allow millions of acres to lie or to get barren, millions of dollars to escape the laboring classes of the future, because the state cannot afford $\$ 50,000$ annually for forest protection? Is it possible that the provimcial functions of government are not sufficiently understood under the regime of democracy? If everything is done "by the people, for the people and through the people," why not forest protection?

I do not know whether constitutional restrictions prevent the rescue of forestry from its main adversaries, fires and taxes; but if they do, why not change the constitution? A constitution which does not allow of adaptation to changed economic conditions, is not for the good of the people. If for one reason or another, private forestry cannot be made a remunerative undertaking through state's authority and aid, then the state itself will have to embark in forestry.

The interdependence between the prosperity of the various forms of industry is nowhere better understood than in the United States. The industry of a country is a quadruped, with manufacture for the head and with the three soil industries (agriculture, mining, forestry) and transportation for the legs. Cutting off one of the legs, we cripple the entire animal.

The decision whether private forestry shall be made remunerative at the expense of the state, or whether state forestry shall be established, must be left to the legislature. To me, a combination of both methods seems most advisable. The state should practice forestry on all nonagricultural land owned by it, after clearing its title to land forfeited for nonpayment of taxes, and private individuals should be induced to practice forestry on their holdings of nonagricultural character. The advantage of the combined system is its greater elasticity. Finding that the one branch is cheaper and more effective than the other, we can gradually emphasize the one and abandon the other. To judge from a century's experience abroad, state forestry is the more advisable system. It is more stable, bears better regard to the people's interest in the forest and spends a comparatively small sum for administration and protection. Under the combined system, the governmental staff of foresters can at the same time protect the private forests from fires and assist in their proper assessment for tax purposes. 
FEDERAL COÖPERATION.

The United States Government can be justly held to concur in paying the forestry expenses of states containing nonagricultural land, the people as a whole drawing advantage from a state forestry system. A division of forestry already exists at Washington, admirably managed by Mr. Gifford Pinchot. The coöperation of its officers can be had almost free of charge. If federal money is engaged in Minnesota's forestry, federal forest authorities must be. allowed to watch its proper application. The American people pay for the administration of the United States forest reserves in the far West. Is it unjust to demand that the people as a whole bear a share of an expense which is incurred-to a large extent-for the benefit of the people as a whole, be it in the East or in the West, in the North or in the South?

In Minnesota, the federal government still owns several million acres of nonagricultural land. This land should be withdrawn from the market, as long as conservative use of its resources in the hands of private parties is impossible, private forestry being unremunerative. All mature timber, of course, should be sold as early as possible, and from the receipts the expense for forest administration and forest development should be covered. If an arrangement can be made by which the administration of federal and state forests, and the protection of private woodlands can be combined, being placed in charge of one and the same official staff, the expense for forestry in Minnesota will be a minimum and its efficiency a maximum.

Love of the forests alone will never bring about forestry. The people ruling this country must be made to see the intrinsic economic importance of forestry. Every leader of the public mind, every teacher, every preacher, every county and state officer, must consider it his duty to draw the people's attention to the necessity of a forest system. There is no room for selfishness in the forestry propaganda. The advocate of forestry can only be a man devoted more to his country than to his private interests. He will have to battle against the state's main enemy, the egotism of its various constituents, fearing loss of taxes for the county, or loss of a chance to obtain timber at a small price. He will have to brave the vociferations of those public leaders who offer to the people at random what the people like to hear, the war-cry against increased public expenses. As long as the people are taught to love the dollar kept in the pocket better than the dollar spent for the country, forestry will have a poor chance to develop. 
I may be permitted to recapitulate the legal steps, which, in my opinion, the people of Minnesota ought to take towards forestry:

I. A law ordering a survey to be made, by which the nonagricultural townships and sections of townships shall be defined.

II. A law pertaining to clear-through the medium of courts, attorneys and surveyors-the state's title to land forfeited for nonpayment of taxes.

III. A law creating an organized staff of forest guards, whose duty it shall be to efficiently protect all private forests, and to enforce the laws enacted relative to federal and state forests and forest lands. This staff might, at the same time, have the duties of fish and game wardens.

IV. A law regulating the assessment of nonagricultural land (compare No. I) for taxation purposes.

V. A law allowing companies to own tracts comprising over 5 , 000 acres for forestry purposes.

VI. A law providing means for investigating the financial possibilities of forestry.

C. A. SCHENCK. 






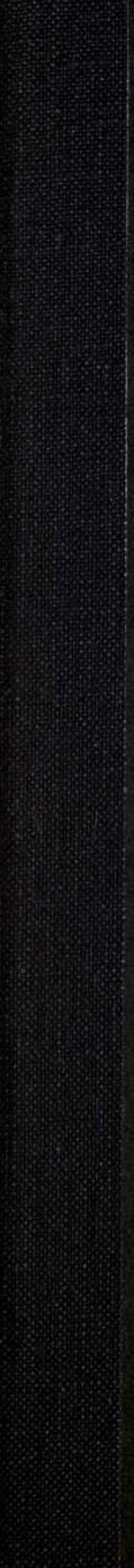


